\section{Research and the Cotton Industry}

THE actual results obtained in the scientific research carried out at the Shirley Institute are the property of the members subscribing and this undoubtedly handicaps the Association in propaganda work. Enough regarding the work, however, was revealed in general terms at the annual meeting to indicate the actual and potential value of the Institute to the industry. The staff has been in contact during the year with more than 90 per cent of the member firms. Results already obtained fully justify Mr. Greg's assertion that economy on research even in the days of bad trade is unwise and unprofitable, and that the Association is worthy of far more generous support by the industry. The number of problems already raised by members which cannot be attacked by the Institute is considerable and the diversion of effort from longrange or fundamental research to current trade problems is a serious threat to the future development and prosperity of the industry. These are matters in which the nation as a whole is vitally concerned, but it cannot be expected that the direct contribution of the State can be materially increased except pari passu with a fitting acceptance by the industry itself of its own financial responsibilities for research.

\section{Archrological Studies in Mexico}

A Decision of the Supreme Court of Mexico, it is reported by Science Service (Washington, D.C.), is expected during the current month, which is of considerable moment for the future study of the archæology of Central America. The point at issue is the control by individual States of the archæological sites within their respective boundaries. For some years the Central Government, largely owing to the influence of Señor Gamio, himself an archæologist of note, has displayed commendable energy in the examination and excavation of the archæological sites of the country. Any decision which would hamper or disturb the organisation of systematic exploration would be unfortunate in the extreme. The arrangements for the season now opening are already complete; but work cannot go forward until the decision of the courts is known. It may be hoped that whatever the verdict, some modus vivendi will be attained to satisfy both local interests and any claims the Central Government may justly put forward on the ground of its superior facilities for organised research.

THE archæological activities which are delayed pending decision are considerable. At Monte Alban, where the now famous gold treasure was discovered in a tomb this year, an appropriation three times as large as that of last year is to be expended in the further excavation of the innumerable tombs on the site ; while stratigraphical study is to be carried on with a view of correlation with Maya sites to the east, south and north. The exploration of a Zapotec fortress known as Quiengola, south of Monte Alban, is to be initiated ; and further explora- tions are to be made in the tomb at Texmelincan, the remote area of Guerrero, from which part only of the contents, including a number of gold objects, was removed at the time of its discovery early this year. In the important Toltec city of Teotihuacan, near Mexico City, the excavation of the "Avenue of the Dead", the mile-long central axis of the city with its row of mounds, now known to be the plat. forms of temples, is to be continued. At Chichen Itzá, which may be considered the strategic point for at least one period of Mayan history, important work on the interior of the pyramid of the Temple of Kukulkan, the Bird Snake, will be carried further. This pyramid, $90 \mathrm{ft}$. high, is the highest in the city, and in last season's excavation was found to enclose a smaller pyramid. It is intended this year to explore this contained pyramid and search for other internal structures. This outline of impending excavation, brief as it is, will indicate the extent of the interests involved in the forthcoming decision, quite apart from any questions which may arise affecting the position of the numerous expeditions from the United States now operating in Mexico.

\section{The Horniman Museum and Library}

THE late Mr. Emslie J. Horniman has bequeathed a sum of $£ 10,000$, free of duty, to the London County Council, for the purpose of providing an extension to the Horniman Museum, Forest Hill. The Museum was built by the late Mr. John E. Horniman, father of the testator, and before it was opened to the public he presented it and its contents, in 1901, to the London County Council. As is usual, and perhaps inevitable, in museums, the collections have since outgrown the accommodation, with the result that cases have become overcrowded, and progress has been hampered. This is more especially so with the collections dealing with the material culture of backward peoples. The provision of additional space will enable the present exhibited series to be opened out and extended, thus furthering that educational arrangement of the collections which has been the constant aim of the Museum authorities. It may be noted that Mr. Horniman's interest in the Museum has been shown in many ways, notably in the pro. vision, in 1912, of an extension for the purposes of a lecture hall and library.

UNDER Dr. H. S. Harrison, who was appointed curator in 1904, the collections have been built up continuously with the view of the function of the Museum as providing material for the study of the development of the arts and erafts of primitive races and the natural history of man and animals. The educational value of the Museum collections has been much enhanced by the excellent series of handbooks, prepared by the staff, which deal, in a scientific spirit, but in not too technical a manner, with the developmental aspect of the collections, illustrating such topics as fire-making, transport, tools from the stone age to the steel age, and the like. The enlightened policy of the education authority for London in promoting lectures on the

No. 3287, Vor. 1307 
Museum collections and related subjects, which teachers are encouraged to attend, has given the Horniman Museum a unique place among the educational facilities of London.

\section{The Royal College of Physicians and Preventive Medicine}

IN his Harveian oration delivered before the Royal College of Physicians of London on October 18, Sir George Newman, chief medical officer of the Ministry of Health, discussed the debt of preventive medicine to Harvey and the College. He showed first of all that Harvey's discovery of the circulation of the blood led directly to the conception of physiological balance elaborated by Claude Bernard, who formulated the synthetic principle that all the vital functions of the body establish jointly a constant and stabie internal environment for the organism living in a variable external environment. Subsequent discoveries proved that physical health and mental capacity depend upon a mutual contribution of nutrition, hormones, nervous regulation and oxygenation of the circulating blood, and that these factors act in the prevention of disease. The application of the Harveian method and spirit to the study of the cause and control of infective disease and artificial immunity was then considered. Sir George maintained that throughout its history the Royal College of Physicians, with which Harvey was so closely connected, has been the foster-mother of sound medical practice and has cultivated the Renaissance spirit of true learning and inquiry. The preventive work of the College is illustrated by its participation in the pharmacopoeias published between 1618 and 1851, after which year this duty was transferred to the General Medical Council by the Medical Act of 1858 ; its recommendations drawn up in 1720 for the prevention of plague ; its petition to Parliament in 1725 which led to the suppression of gin shops and the restriction of private retail sales; its constant advocacy of vaccination; the introduction of registration of the causes of death and the nomenclature of disease in 1837 ; and the creation in conjunction with the Royal College of Surgeons of a diploma of public health and afterwards of a similar diploma in tropical medicine and hygiene. In conclusion, Sir George dealt with the development of a communal medical service and emphasised the necessity of mutual co-ordination between all channels and means of medical activity.

\section{Chaucer and Contemporary Medicine}

AT a meeting of the Osler Club on October 21, Dr. J. D. Rolleston read a paper on "Chaucer and Medieval Medicine", which he commenced by a quotation from the modern version of some of the "Canterbury Tales" published in 1700 by Dryden, who after describing Chaucer as the father of English poetry continues: " $\mathrm{He}$ is a perpetual fountain of good sense, learned in all sciences and therefore speaks properly on all subjects. . . Chaucer followed Nature everywhere, but was never so bold as to go beyond her." Although a few references to Chaucer are to be found in the works of some British medical historians, no essay dealing with the allusions to contemporary medicine in his works has hitherto been published, if one may judge from the absence of any entry in the Surgeon-General's Catalogue relating to Chaucer, in striking contrast with medical articles on Shakespeare or Goethe or even Dante and Byron. Dr. Rolleston, however, maintained that not only in the "Canterbury Tales", including the lengthy prose discourses of Melibeus and the Parson, as well as in Troilus and Criseyde, but also in many of the minor poems, there is much to interest the medical reader as well as delight the literary student. After a brief sketch of Chaucer's life, during which the poet became acquainted with all ranks of society, including men of science and learning, Dr. Rolleston dealt with the passages of medical interest in his works under the four headings, the medical profession in Chaucer's time, prevalent medical doctrines, diseases and their treatment, and miscellaneous topics.

\section{Monument to Ernest Solvay}

ON October 16 in the presence of the King of the Belgians and the Duke of Brabant, a monument was unveiled in Brussels to Emest Solvay, the eminent chemist, philanthropist and publicist. Solvay was born at Rebecq in Brabant on April 16, 1838, and died in Brussels on May 26, 1922. The foundation of all his success in chemical industry and his immense wealth was his discovery of the ammonia-soda process. To the unfortunate Nicholas Leblanc (17531806), whose statue stands in front of the Conservatoire des Arts et Mótiers in Paris, the world owed the first successful process for manufacturing artificial soda, and by 1863, the year in which Solvay took out his patent, the world production of soda was about 300,000 tons a year. The Solvay process, after the many initial difficulties had been overcome, proved far more economical than the Leblanc process, and by 1914 there were some twenty-three works in various parts of the world engaged in the Solvay ammonia-soda process, capable of producing about $2,000,000$ tons of soda ash a year. Mr. Runciman, President of the Board of 'Trade, in a speech delivered on October 20, when dealing with the question of trade recovery, said that "one first-class invention is worth fifty Acts of Parliament". To that class of invention Solvav's belongs.

\section{Trevithick Centenary}

THE centenary of the death of Richard Trevithick occurs next April and steps have been taken by the Newcomen Society to commemorate Trevithick's life and work. In response to an invitation sent out by the Society, there was a large gathering of representatives of engineering institutions from many parts of Great Britain at a meeting to discuss the matter held at the Institution of Civil Engineers on October 20, and a committee was formed to deal with the commemoration as an international affair. The president-elect of the Institution of Civil Engineers is to be asked to be chairman of the committee and Mr. H. W. Dickinson, honorary secretary of the

No. 3287, Vol. 130] 